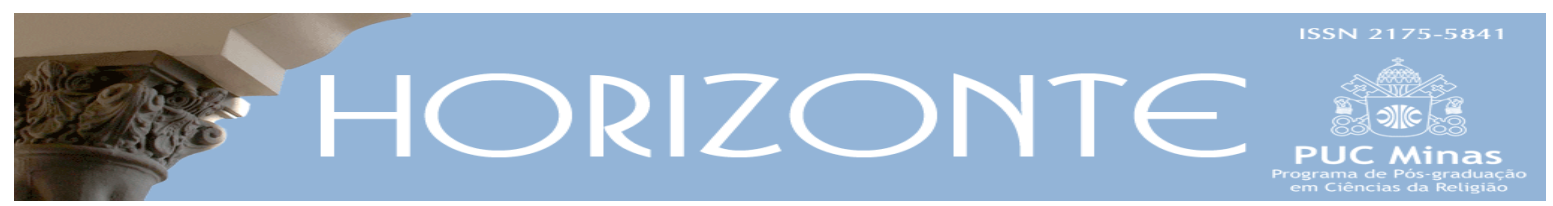

Temática Livre - Artigo Original

(c) (i) $\mathrm{DY}$ - 10.5752/P.2175-5841.2016v14n43p1064

\title{
Implicações pastorais da liberdade humana em Juan Luis Segundo
}

\author{
The pastoral implications of human freedom according \\ to Juan Luis Segundo
}

Vicente de Paula Ferreira*

\begin{abstract}
Resumo
O artigo discute a questão da liberdade humana a partir de relevantes princípios da fé cristã numa época de vulnerabilidade antropológica, sobretudo na realidade latino-americana. Sustenta-se que o Cristianismo deve insistir em sua proposta de construção da fraternidade universal, apesar dos cenários marcados pelo egoísmo, reforçado pela exacerbação do poder e do dinheiro. Esta abordagem pressupõe a radical condição de ouvinte do mistério divino, revelado em Jesus Cristo, como caminho de plenitude da condição humana. A estrutura teórica da Teologia da Libertação, na visão de Juan Luis Segundo, em sua vasta tradição de defesa de uma fé que seja transformadora das realidades de injustiça, será o ponto de apoio para o presente texto. Será também objetivo mostrar que a salvação cristã necessariamente implica a kênosis de Jesus, isto é, Cristo “esvaziou em si mesmo" (FI 2, 7), e em seu humilde despojamento, rompeu com os sistemas fechados do mundo, promovendo a inédita aventura de uma liberdade libertada: o amor ágape. Conclui-se que a práxis cristã pode ser entendida como cuidado cotidiano para com os mais pobres e profecia do perdão enquanto resgate da memória das vítimas de toda forma humana egoísta.
\end{abstract}

Palavras-chave: Liberdade. Kênosis. Salvação. Cristianismo.

\begin{abstract}
The paper aims to reflect the issue of human freedom based on the underlying principles of the Christian faith in a time of anthropological vulnerability, especially in Latin American. It holds that Christianity must insist on its proposal to promote universal goodwill, despite a human horizon marked by selfishness and lust for power and money. This approach presupposes a radical position of a listener of the divine mystery, revealed in Jesus Christ, as a way to fulfill the human condition. Theoretical framework: Liberation Theology, in the view of Juan Luis Segundo, and its well-established tradition of transforming realities of injustice through faith, comprises the core argument of this text. Findings: Christian salvation necessarily implies the kenosis ( $k \dot{v} v \omega \sigma \iota \varsigma)$ of Jesus, i.e., Christ "emptied Himself" (Ph. 2:7), and through His humble dispossession, He broke with all closed systems of the world, and inaugurated a new venture of a liberated freedom: the agape of love. Conclusion: Christian praxis as daily care for the poorest and prophecy of forgiveness rescues the memory of the victims of all forms of human selfishness.
\end{abstract}

Keywords:Freedom. Kênosis.Salvation.Christianity.

Artigo recebido em 26 de março de 2016 e aprovado em 21 de setembro de 2016.

*Doutor em Ciência da Religião pela Universidade Federal de Juiz de Fora, MG, bolsista do PNPD/Capes na Faculdade Jesuíta de Filosofia e Teologia (FAJE) e membro do grupo de pesquisa Interfaces da Antropologia na Teologia contemporânea, na mesma faculdade. País de origem: Brasil. E-mail: pe.vicente@veloxmail.com.br

Horizonte, Belo Horizonte, v. 14, n. 43, p. 1064-1092, jul./set. 2016 - ISSN 2175-5841 


\section{Introdução}

Para abrir a presente reflexão, são elencadas algumas perguntas como inspiração para o caminho que se propõe seguir. Será que a humanidade enfrenta, pela primeira vez, na aldeia global, a possibilidade de um aniquilamento que vai desde sua esterilidade pela falta de sentido existencial até a incapacidade de fazer da vida uma aventura relacional fraterna? No meio das sombras de uma era pósmoderna, reforçadas por aceleradas ondas de violência e desconfiança do outro, pela perda de sentido e desejo em gastar a vida por alguma causa comum, ainda seria possível reconhecer um fundo místico e profético salvífico na espécie humana? E como se coloca a fé cristã, hoje, a respeito do que realmente seja a liberdade humana para que não se acomode em experiências religiosas alienantes e que não promovem o humanismo mais radical?

Outros elementos poderiam ser elencados como pontos de preocupações ou, de outra forma, algumas luzes dos cenários atuais como os avanços técnicocientíficos, o esforço de grupos pela defesa da democracia, da dignidade dos mais pobres. No entanto, pretende-se colocar em foco a liberdade humana, não simplesmente como dom de fazer escolhas categoriais nas urgências cotidianas, porém e, sobretudo, como inquieta indagação do homem contemporâneo sobre o que fazer com sua espécie. Hoje, muito mais que em eras passadas, responder a essas perguntas não se trata de tarefa fácil porque em suas mãos, pelo menos parte da humanidade, possui instrumentos suficientes para alcançar saltos significativos em relação à dignidade universal ou, paradoxalmente, meios fortes de autodestruição. Por isso, o foco central do presente artigo é a liberdade e qual forma de cristianismo pode auxiliar em sua clarificação e no encorajamento da construção da fraternidade.

Certamente o esquema estático, que compreendia uma verdade universal antropológica à qual toda pessoa deveria corresponder, não dá conta da liberdade 
em seu sentido mais amplo e de entender os processos de mutação, de interpretação do ser humano. A dificuldade maior de sistemas metafísicos mais fechados encontra-se em conceber o ser humano interdependente, de maneira particular em tempos de pluralismo cultural. Entender, hoje, a dignidade humana sem levar a sério que toda existência é uma interpretação, uma construção, enfraqueceria o fato essencial de que a revelação cristã mostra o ser humano como parceiro de Deus na obra não terminada da criação. Assim sendo, o presente artigo pretende mostrar que o ser cristão seria a descoberta alegre de que na vulnerabilidade habita o chamado para um caminho de investimento da liberdade na construção de relações pautadas no amor solidário. $\mathrm{O}$ amor divino é pura gratuidade que transcende qualquer meritocracia, elevando o ser cristão a uma vida nova, no Espírito, capaz de curar, de perdoar, de incluir, de partilhar. Assim, espera-se abrir horizontes de confiança para um agir pastoral criativo numa Igreja chamada a ser fermento de vida na massa.

\section{O drama latino-americano da dignidade humana e a questão da liberdade}

No contexto latino-americano, em aproximadamente cinco séculos, a evangelização conviveu com massas de pessoas exploradas como os índios e os escravos. Da mesma forma, a dependência dos povos latino-americanos de um sistema neo-liberal atual, orientado pelo predomínio econômico, é algo real que ameaça sobretudo as conquistas sociais, as culturas menores, as iniciativas solidárias. A fé cristã, sobretudo diante de diversas inseguranças de uma democracia ainda frágil e do retorno de inúmeras posturas fundamentalistas ou relativistas presentes nos setores políticos, religiosos, educacionais, é convidada a repensar sua missão de defesa da vida. Nesse sentido, a Teologia da Libertação, na tentativa de unir fé e vida, não deve restringir a questão da libertação em seus aspectos puramente sociológicos ou demasiadamente escatológicos. O desafio é buscar uma ortopraxia respaldada pela ortodoxia da palavra libertação 
(GUTIÉRREZ, G.; MÜLLER, 2013). Por isso, é importante traçar uma justificativa da escolha da categoria libertação no cenário da teologia atual ${ }^{1}$.

Nesse sentido, são iluminadoras as perguntas do teólogo Juan Luis Segundo (1983), que são apresentadas a seguir. Salvos de quê? Curas, multiplicações dos pães, o perdão inclusivo, são sinais muito claros de uma crítica que Jesus faz às pessoas e grupos que oprimem em nome de Deus (Mc 6, 34ss; Mt 21, 33. 43-46). Ainda que não termine no campo restritamente material, a libertação é prioritariamente material. Começa pelas situações nas quais as energias humanas são escassas. Jesus prefere as vítimas mais radicais da exploração e convoca o ser humano para participar do Reino de Deus. Paulo, em sua acurada interpretação da liberdade afirma que se Cristo não for para o cristão a travessia desse umbral da liberdade "Cristo de nada vos servirá" (Gl 5,$2 ; 3,4$ ). "Vós fostes chamados à liberdade, irmãos." ( $\mathrm{Gl} 5,13)$. Paulo não fala como Jesus, de Reino, que significa a chegada da libertação em relação a tudo que é escravidão. Paulo preocupa-se com a liberdade graças à qual todo ser humano pode cooperar com a "seara de Deus, edifício de Deus" (1 Cor 3, 9).

Com isso, Paulo muda a possibilidade de qualquer discurso moralizante sobre as bem-aventuranças, proclamando que Jesus revela ao ser humano os segredos mais importantes sobre a humanidade na terra. Jesus foi apresentado por Paulo, em sua chave antropológica, fazendo a passagem da terminologia Reino de Deus, que pode incorrer no equívoco de se pensar numa ação de mão única, a de Deus, para a terminologia agricultura ou construção, que especificam com mais clareza a participação conjunta de Deus e do homem na obra da criação. Synergountes, cooperadores, é categoria forte da nova antropologia paulina. Todavia, essa cooperação não seria eficiente caso o homem não fosse livre, nem

\footnotetext{
${ }^{1}$ De acordo com SEGUNDO (1983) o termo salvar aparece 106 vezes nas escrituras e sublinha a ação de arrancar, salvar de um perigo por uma força superior. Jesus define o presente que com ele chegou, presente de salvação e libertação (Lc4, 18-19). A Conferência Episcopal de Medellin dizia que há libertação quando se passa de uma vida menos humana para outra mais humana. A salvação é o inclinar amoroso de Deus em direção à fraqueza do ser humano para lhe dar confiança e força para seguir seu caminho. Redenção e salvação são realidades que não podem ser restringidas a uma expectativa somente escatológica sem levar em conta a vocação da liberdade humana para a construção do Reino de Deus (Mt 6, 33; 25, 24-26). Deus estabelece seu Reino e esse Reino é libertação.
} 
tanto para escolher entre bem e mal, porém para que haja possibilidade de projetar e levar a termo seus projetos de ágape. Isso significa um salto para liberdade. Sair definitivamente da escravidão do temor ( $R m$ 8, 15). Ou seja, sair da angustiante contabilidade das obras como meio de salvação. O medo que obstrui novas formas de construir ágape, segundo Paulo, pertence ao estágio infantil do ser humano. Jesus põe fim a esse processo. Ele, o Filho, mostra a filiação do ser humano. De modo que, n’Ele, o homem recebe a filiação ( $\mathrm{Gl} 4,5 ; \mathrm{Rm} 8,16)$. Na infância, costumava-se perguntar a outros seres, à lei, pela validade do agir. Agora, na vida adulta, ao invés de perguntar pela licitude moral, deve-se perguntar pela conveniência diante de um projeto mais amplo da liberdade. "Tudo me é permitido, mas nem tudo convém” (1Co 6, 12; 10, 23).

Não se coloca uma projeção desde fora. É preciso consultar as leis do universo para ver o que mais convém com o projeto. Essa é a virada antropológica de Paulo, sobretudo no que concerne à responsabilidade do ser humano diante de sua vocação filial. E tais projetos, para os discípulos de Jesus, não são outra coisa que a criação do amor na história, diante das necessidades do irmão (1 Cor 10, 24, 28-29; Gl 5, 13; Rm 13, 8-10). Acontece que esta liberdade está ameaçada sempre e até mesmo por estruturas religiosas. Em muitas ocasiões o homem tenta negociar com Deus para que fique livre do fardo de uma liberdade criativa, colocando sua confiança no cumprimento literal da lei de Moisés (Gl3, 15ss; 4, 5. 21-31). Ou o homem pode também enfraquecer sua liberdade pelos vícios e paixões, pelos atalhos da liberdade. Sendo assim, o maior perigo é que a liberdade criadora se transforme em peso porque se trata de criar com instrumentos já criados. E as leis do universo não respeitam muito a criatividade humana, por isso é mais fácil a comodidade, mais tranquilo entrar no mundo da instrumentalidade, fazendo opção por orientações de massa.

O pecado maior, portanto, é sucumbir-se aos mecanismos que não levam à realização do projeto amoroso, ainda mais porque nesse processo muita coisa fica oculta, escondida na história, não respeitando posturas de juízos apressados. Para 
Paulo, a definição mesma de ressurreição será a superação da tensão entre fazer o mal que não quer e não fazer o bem que quer ( $R m$, 19.21). O encontro da graça com a concretização histórica do homem faz nascer o que o Antigo Testamento e Novo Testamento chamam de "Novo céu (de Deus) e a nova terra (dos homens)" (Ap 21,1; 2 Pd 3, 13). Ou, de acordo com Concílio Vaticano II, "os bens da dignidade humana, a união fraterna e a liberdade, limpos e transfigurados, quando Cristo entregue ao Pai o reino da verdade e de justiça, que já está misteriosamente presente em nossa terra" (GS 39).

Para superar o medo da liberdade e outra vez não colocar a confiança no cumprimento cego das leis, negociando com Deus, o homem deve ter fé ( $\mathrm{Gl}_{3}$, 2324). Colocar a vida nas mãos de Deus, realizando o que Ele deu ao homem como fonte de construção do reino que é a história. Pode o homem deixar para Deus a questão definitiva da história? Pode mediante "o amor de Deus derramado em nossos corações” (Rm 5, 5). Assim fica explicitada a circularidade entre libertação, que Deus mostra em Jesus Cristo, na sua opção pelos pobres, e a liberdade que concede ao homem para continuar atuando nessa mesma história em favor das situações menos favorecidas. Assim se explica porque a Teologia da Libertação dá ênfase à palavra libertação, por ter entendido que durante muitos séculos o cristianismo latino-americano conviveu com uma falta de ortopráxis, dando as costas para situações de injustiça. Inclusive incutindo no pobre a triste conclusão de que a miséria é vontade de Deus. Portanto, liberdade cristã não tem nada a ver com liberdade de gozar a vida usufruindo de seus bens sem limites. Somente há liberdade cristã quando se combate a pobreza, com projetos históricos de mãos dadas com o senhorio de Deus que presenteou ao homem a graça de transformar as situações de morte ${ }^{2}$.

\footnotetext{
${ }^{2}$ Em seu extenso livro Ética da libertação, na idade da globalização e da exclusão, Enrique Dussel afirma que escreve essa obra para tratar de "uma ética cotidiana, desde e em favor das imensas maiorias da humanidade excluídas da globalização, na presente normalidade histórica vigente" (2000, p. 15). Desse modo, o tema da libertação não está presente apenas num horizonte teológico, mas encontra-se nas preocupações de uma ética filosófica que assume a defesa das vítimas produzidas por uma época globalizada.
} 
O testemunho de tantos homens e mulheres que se doam aos mais pobres, às vítimas cujo clamor chega aos céus, na vasta América Latina, mostra que a liberdade humana não passaria de abstração racional caso não encontrasse seu expoente mais aberto na solidariedade para com o pobre. "O rosto desfigurado do outro, a ausência lacerante de quem foi aniquilado, e o clamor dos inocentes que são injustiçados por qualquer sistema de totalidade, são transfigurados pela vida entregue dos justos da história" (MENDOZA-ÁLVARES, 2015, p. 49). É a partir da história das vítimas que se pode construir relances de esperança de uma alteridade verdadeiramente encarnada e livre. Caso houvesse um esquecimento total das pessoas dilaceradas pela história, seria engodo falar de alteridade e de liberdade em seu sentido mais radical. O perdão da vítima abre na história a dimensão escatológica da vida nova e a realização mais nobre da vocação humana. Dimensão não delegada somente para um depois, porém que instaura ordem nova do tempo, da história como fonte de reconciliação3.

De modo que a liberdade humana já não pode mais "definir-se, como no modelo ilustrado, somente a partir dos direitos individuais e sociais como autoafirmação egoísta sem relação com os outros, senão que será preciso postular uma codificação ético-jurídica em chave kenótica de doação (MENDOZA-ÁLVARES, 2015, p. 53). É na dignidade vulnerável da pessoa do pobre que hoje permanece Deus escondido, enfraquecido. Nela está adormecida a possibilidade de uma nova humanidade. Falar de liberdade cristã pós-moderna sem abordar com coragem esse vazio produzido pela violência em relação às vítimas, que lança perguntas importantes a todas as religiões e que, em Cristo Jesus, se revela e oculta como perdão incondicional, que redime a todos, seria cair na inércia de uma religiosidade que não leva ainda a sério o que é próprio da religião cristã. Que de fato, no seu mistério infinito de amor, Deus entregou o mundo ao homem para que ele exercesse sua liberdade de amar. Não somente entregou como também o libertou

\footnotetext{
${ }^{3}$ Sobre as incidências de um fazer teológico que leve em conta grandes temas atuais, de modo particular para o contexto latinoamericano, ver as várias reflexões sobre Teologia e sociedade (BAPTISTA; SANCHEZ, 2011) e as atualizações teológico-pastorais sobre a temática Fé cristã e pensamento evolucionista (AMADO; RUBIO, 2012).
} 
de forma mais radical na páscoa de Jesus, dando-lhe a confiança, a força, o espírito necessário para levar adiante sua missão de filho de Deus. Caso o cristianismo não se confirme como instância crítica de uma realidade social exclusivista, nos horizontes da pós-modernidade latino-americana, facilmente ele reforçará a forte tendência de ser uma religião intimista que enfraquece o compromisso com a solidariedade. Ou, de outro modo, terá a triste sorte de estar entre "as religiões idolátricas, as que usam o nome de Deus para legitimar a opressão, a morte dos pobres, a exigência de sofrimento e sacrifícios dos pobres para o bem do reino e da nação...” (SUNG, 1992, p. 22).

\section{Itinerários da libertação da liberdade}

Pretende o cristianismo realizar uma salvação extra-mundana, esquecendose do que Paulo e João disseram que a salvação se realiza na história? Para responder a essa pergunta, Juan Luis Segundo toma três questões básicas: salvos de quê? Quem salva? Como salva? Os escritos primitivos dirão que salvação está relacionada a qualquer tipo de males. Noé é salvo do dilúvio, o povo é livre da escravidão no Egito (At 7,25). Muitas vezes salvar significa cura de um enfermo, de um coxo (At 14, 8). Salvar diz respeito a um mal, que pelo temor faz surgir a exclamação "Senhor, salva-me”, conforme gritou Pedro. No entanto, tem o sentido mais profundo de ser a libertação do mal que afeta a todos, a morte (Jo 12, 27). Então quem impede de alguém cair no mal é salvador. Logo, quem salva é sempre o outro; Deus, conforme mostra o Novo Testamento. Qual a relação entre o salvador e aquele que é salvo? Acontece na inesperada doação daquele que salva e na fé do que é salvo.

Esse é o significado em relação aos males profanos, que mostra Deus salvando não de realidades sobrenaturais, mas com intervenções na realidade concreta, na escravidão, nas desgraças, na enfermidade, na morte. Desde a tradição da Sabedoria até os Evangelhos acontece uma passagem importante. A pergunta 
era: como acontecerá a justiça divina? Ora, existe um juízo de Deus que acontecerá depois da morte e assim se configura um salto na compreensão de salvação. De maneira que,

um elemento decisivo entra assim a formar parte da visão religiosa: a distinção radical entre o que poderíamos chamar de males relativos, que são os que têm lugar no tempo da existência terrena, e o "mal absoluto", aquele que relativiza todos os demais: a condenação definitiva extra mundana que segue ao juízo de Deus para o homem que não praticou a justiça (SEGUNDO, 1983, p. 80).

Na tradição do livro da Sabedoria, encontram-se elementos sobre a salvação que chegam ao Evangelho, fazendo do cristianismo, até certo ponto, uma religião extramundana. A justiça não está sujeita à morte ( $\mathrm{Sb} 1,15)$. E com isso existe algo de imortal na existência mundana. Existe a liberdade de escolher o absoluto. Os ímpios apostam na morte, porém se ela não é o fim, terão colocado tudo a perder. A justiça não está sujeita à morte, por isso sua esperança está cheia de imortalidade. Além disso, o homem, na existência atual, é provado pela lei de Deus. Ou seja, essa existência só tem valor de prova e não em si mesma. O homem religioso é movido pela esperança do além. O ímpio, ao valorizar somente essa vida, fica na ordem do aquém.

Cristo surge neste contexto e várias passagens do Evangelho estão de acordo com ele (Hb, 1; Tiago, 1Pedro). Três elementos essenciais vieram da Sabedoria. A questão da imortalidade, "Deus nos regenerou para uma esperança viva, para uma herança incorruptível, incontaminada, imarcescível, conservada nos céus para vós que sois guardados para a salvação” (1Pd 1, 3-5). A esperança que fortalece o homem na vivência dos males atuais. "Que adianta, meus irmãos, se alguém diz ter fé, mas não tem obras? Acaso pode a fé salvá-lo?” (Tg 2, 14). E o homem sujeito de sua salvação, no entanto tendo a existência apenas como tempo de prova. Mas será que Jesus é uma continuação restrita dessas tradições? Para responder a essa pergunta, é necessário colher a força do testemunho de Paulo que não se contentou em reproduzir o que já existia. Foi um criador para seus contextos próprios. Nesse 
sentido, juntamente com João, “aparece como o primeiro a construir um pensamento diretamente cristão, se assim se pode dizer, isto é, um enfoque da totalidade da existência em razão da nova mensagem” (SEGUNDO, 1983, p. 83).

Como Paulo responde a essas três questões de que o homem é salvo, quem o salva e como? Paulo jogou a salvação para seu aspecto intramundano. Se antes o ser humano era pecador, agora já está reconciliado com Deus ( $\mathrm{Rm} 5,10)$. O futuro está baseado no presente, porque ser filhos adotivos e a libertação do corpo são elementos novos. "O Espírito dá testemunho ao nosso espírito de que somos filhos de Deus. O essencial da salvação é, pois, segundo o pensamento de Paulo, um fato concreto intramundano" (SEGUNDO, 1983, p. 85). Mesmo que a criação continua gemendo em dores de parto, o homem possui o espírito da liberdade. A libertação do corpo se fará plenamente, porem já se inicia aqui, na vida no Espírito. "Deus nos livrou de toda ação e nos fará salvos em seu reino celestial” (2Tim 4, 18). A salvação já acontece no mundo, em meio aos sofrimentos. O germe da morte, o pecado, foi vencido. A salvação para Paulo possui esse forte fator existencial da vida intramundana do homem. Assim Paulo responde à pergunta sobre quem salva. "Pela graça fostes salvos, por meio da fé, e isso não vem de vós, é o dom de Deus" (Ef 2, 8). É o amor misericordioso que salva (Tit3, 4-5). A salvação é uma proposta totalmente gratuita de Deus. Assim sendo, colocar em prática a salvação recebida gratuitamente é "condição indispensável para compreender a inserção da salvação na história intramundana da humanidade e reconhecer a sua amplidão universal" (SEGUNDO, 1983, p. 88). Portanto, se quem salva é Deus, o que resta ao ser humano? Resta compreender como salva o Deus que salva. Não o faz como gesto extrinsecista, porém como convite para traduzir a salvação em obras, pela fé, pela confiança e entrega ao salvador. É a atitude de gratuidade da nova criatura. Não se comercializa com Deus, fazendo coisas, para que em troca Ele conceda a salvação. A existência, já transformada pelo dom absoluto divino, passa a ser resposta livre.

É nesse sentido que Paulo afirma que "tudo é lícito, mas nem tudo edifica" (1 Cor 6,12$)$. Se a salvação é de fato uma transformação da história, a moral não pode 
ser mais uma questão de liceidade, porém projeto realizado no tempo. É preciso substituir o que é lícito pela busca contínua do discernimento do que seja conveniente. Ser cristão é um projeto em construção a ser levado a cabo concretamente. Somente assim se livra de uma servidão legal. "A moral que deriva, portanto, da autêntica noção da salvação cristã é uma moral criadora, quer dizer, uma moral que não recebe seus preceitos do mundo, mas do projeto que a liberdade do homem deve imprimir num mundo que é seu” (SEGUNDO, 1983, p. 89). A consequência mais radical de tal teologia é a conclusão de que "nenhum de vós vive para si” porque amar é a única lei cristã. A lei que distribui etiquetas do que seja permitido ou proibido, necessita ser superada por outra perspectiva que "indica à liberdade do homem seu único caminho verdadeiro: criar, em circunstâncias sempre pessoais e únicas, um amor histórico também insubstituível e único” (SEGUNDO, 1983, p. 89).

O êxito histórico é radicalmente a novidade da moral cristã. Mesmo que seja um êxito escondido, no entanto, “nada dispensará o cristão de visar o êxito histórico de seu amor, e não haverá vida futura em que se lhe dê o que ele não tenha buscado sinceramente em sua existência humana e temporal" (SEGUNDO, 1983, p. 90). Amor que precisa de discernimento porque sempre haverá indícios de pecado no interior de toda ação amorosa atrelada ao egoísmo. Por isso, o pecado é muito mais do que fazer isso ou aquilo errado. É enfraquecer, colocar a liberdade a perder-se, escolhendo os atalhos do egoísmo que dispersa a liberdade do amor. A moral cristã é criadora e progressiva; à medida que ama descobre mais e mais a força do amor. A moral cristã deve ser entendida também em sua dimensão essencialmente social. Se por um lado o amor não constrói para si e sim constrói o corpo de Cristo, o egoísmo constrói simplesmente. Mais ainda, a moral não somente é criadora, progressiva e social, mas também significativa. É um diálogo atento aos sinais do mundo na medida em que implica toda pessoa com um caminho, uma história a ser construída. 


\section{O sentido comum de religião e a novidade cristã}

A partir das verdades reveladas, o cristianismo sempre se caracterizou por uma busca de aprofundamento sobre quem é o homem, dando relevância no aspecto de uma liberdade redimida e promotora do perdão. Realidade que deve ganhar configurações em cada tempo, enfrentando os desafios e as possibilidades de cada época. "Se o cristianismo pretendesse ser a resposta pré-fabricada e fixa, de uma vez para sempre, dos problemas de todos os homens de todos os tempos, seria a mais gigantesca tirania espiritual da história" (SEGUNDO, 1970, p. 16). Em cada época existe a árdua tarefa de captar qual seria a imagem cristã do homem e essa é uma das missões mais importantes para a antropologia teológica. Diante das feridas que a pós-modernidade apresenta, umas das principais é o crescimento da diferença entre uma minoria da população detentora de grandes cifras da riqueza mundial e a maioria da população que sofre até mesmo por falta de recursos em relação às suas necessidades básicas ${ }^{4}$.

Em sua origem, o cristianismo teve duas revoluções religiosas inéditas que podem iluminar essa busca, de acordo com Juan Luis Segundo (1970). Se a filosofia grega, muito mais do que o pensamento hebraico, ocupou-se em buscar definições sobre Deus, como princípio imutável; para São João, Deus é amor. Deus passou a ser uma relação pessoal, justa e bondosa. E o cristianismo, então, mais do que uma simples teoria de Deus como amor, assumiu a profecia da vivência do amor concreto, da defesa da dignidade de toda pessoa humana. Assim, ficou estabelecida, "como condição e norma para aceder ao conhecimento da divindade, a experiência humana do amor, que é dom e generosidade. Com efeito, é preciso não se esquecer que o termo grego para designar aqui o amor não é eros, o desejo, mas ágape, o amor dom, comunidade" (SEGUNDO, 1970, p. 24).

\footnotetext{
${ }^{4}$ Nesse sentido, é iluminadora a obra "Deus numa economia sem coração, pobreza e neoliberalismo: um desafio à evangelização" (SUNG, 1992). Nela o autor destaca que "a crítica teológica da economia, portanto, além de ser uma das grandes novidades e contribuições da teologia latino-americana, é um dos principais desafios a ser vencido na evangelização" (p. 7). Ao fazer referência a Enrique Dussel, mostra a dramática situação de fetiche e idolatria presentes no sistema capitalista. Destaca que "a fetichização é o processo pelo qual se absolutiza o fundamento do sistema, com o objetivo de sacralizá-lo e, assim, realizar a vontade de poder" (p. 89). Tanto Jung MoSung quanto Enrique Dusselapresentam contribuições valiosas na perspectiva da presente reflexão sobre as consequências pastorais de um processo de libertação cristã.
} 
Como é possível saber desse amor? Ele foi visto na sua auto-doação extrema (Jo 3, 16). Tal experiência é a identidade máxima de toda a existência cristã (Mt 22, 39; 1 Jo 4, 20). Resumidamente, "se alguém diz que ama a Deus e não ama a seu irmão é um mentiroso. Porque quem não ama a seu irmão a quem vê, como poderá amar a Deus a quem não vê?” (1Jo 4, 20). Portanto a materialidade da vocação cristã transparece na fragilidade de quem ama, chegando à vulnerabilidade da própria fonte do amor. Não que isso signifique que se ama o irmão para amar a Deus; porém o amor ao irmão se encontra com o próprio amor de Deus, como fonte única de ágape. De modo que ágape não se compreende sem o dom divino que se faz concretude na forma de um bom samaritano. Daí que o critério do juízo final seja o amor ao mais pequenino (Mt 25, 31-40). Esse aspecto é revolucionário na história das religiões. Partindo dessa consciência exposta nos textos bíblicos, seria o cristianismo apenas uma religião entre as outras ou se trataria de uma revolução que torna absoluto o universo humano?

Depois de dois milênios, quando se escuta textos como os do juízo final, não se pode pensar que o cristianismo seja uma religião como se conhece religião no ocidente. Religião, de acordo com Juan Luis Segundo, geralmente é entendida como cumprimento de certos ritos, crença num incomparável valor absoluto e a relação do indivíduo com um poder maior do que o ser humano. O rito é a busca de um auxílio divino, num espaço separado do profano. Porém, Jesus pede que, se diante do altar houver lembrança de rivalidade, a oferta deve ser deixada para primeiro perdoar o irmão (Mt 5, 23ss). Mais ainda, há uma promessa: adorarás em Espírito e verdade (Jo4, 19-24). Em segundo lugar, todas as religiões supõem adesão a um determinado credo como acesso ao divino, como forma única de conduzir à salvação. Também nesse sentido o cristianismo não seria uma religião porque o juízo final não será uma pergunta pela adesão a um credo, mas pela realização do amor ágape. Ao afirmar que o homem passa da morte a vida por amar o irmão, tal assertiva não significava um evento pontual, porém que acompanha o homem desde que ele é homem. Por isso o cristianismo, em suas origens é universal. Porque reconhece em toda a humanidade o ponto único de salvação que 
é o amor ao próximo. A salvação de Jesus Cristo não é um começo isolado que se irrompe a partir de sua realidade histórica, como se antes os homens não tivessem também sido interpelados por tal amor. Jesus plenifica, desvela o que já está impresso no coração do homem, desde sempre, pela livre bondade de Deus, que o absoluto de Deus se traduz no amor ao irmão. Ao condenar qualquer tipo de magia sagrada que torne o homem irresponsável, inaugura a confiança pascal do mandamento do amor novo. Confirma que "Deus é amor e que todo amor efetivo se converte em valor absoluto, no único valor verdadeiramente absoluto da existência humana” (SEGUNDO, 1970, p. 41).

A segunda revolução do cristianismo que propõe Juan Luis Segundo é a que acontece com o corte em relação à concepção de religião enquanto senhorio de Deus em detrimento da história, do homem. Ao homem restaria um acatamento serviçal às leis já impostas por Deus, expressas na natureza e na Igreja. São Paulo, mais uma vez, teve que enfrentar esse drama da liberdade humana. Assim escreve, "Cristo nos deu a liberdade. Por favor, permaneçam nela e não voltem a aceitar a escravidão” (Gl 5, 1). Para São Paulo, a subserviência à natureza e à Igreja, enquanto estruturas prontas, seria uma atitude de desconfiança em relação à liberdade trazida por Cristo. Seria uma volta à escravidão. Mas se o cristianismo é uma religião universal, como entender os textos como o de Mc 16, 15ss que fala de Cristo e sua Igreja? De outra forma, como entender que Cristo tenha querido uma Igreja mesmo realizando uma revolução laica em relação às estruturas religiosas de sua época?

Já foi dito que Jesus não iniciou algo totalmente novo, ao revelar que o que salva é o amor porque essa verdade pertence à universalidade salvífica de Deus. No entanto, foi Ele, em sua história, que deu visibilidade plena a essa graça do homem, vivendo-a plenamente. A revelação cristã é a luz que autoriza o homem, ainda mais consciente, a seguir o caminho da fraternidade. Se antes essa convicção guardava certa obscuridade espontânea, pela fé reflexa ela ganha em clareza. Espontâneo é o amor que todo ser humano sentiu na vida. Agora ele é iluminado. Sabe de onde 
vem e para onde vai. Ganha maturidade e confiança. É por isso que necessita de comunidade, estrutura organizada. "Como haverá quem creia se não tiverem ouvido? E como ouvirão se não houver quem pregue? E como haverá quem pregue se não houver alguém que envie pregadores?” (Rm 10, 14s). A igreja é uma sociedade organizada para difundir essa mensagem salvífica de Jesus. O cristão sabe que deve viver essa graça que é sempre dom de Deus, de forma aprofundada. É por isso que conta com os sacramentos. De modo que, "o cristianismo poderia chamar-se a religião do amor verdadeiro, e a Igreja cristã é a organização especial destinada a ajudar a essa realidade comum a todos os homens mediante uma consciência mais profunda e mais certa da orientação e do termo desse caminho" (SEGUNDO, 1970, p. 50). De forma ainda mais aguda, São Paulo condena a escravidão em relação a qualquer estrutura eclesial. O risco da acomodação é grande e a vigilância para que não se caia na escravidão deve tornar-se contínua. Fora da Igreja não há salvação se isso for entendido como fora do movimento universal da solidariedade não há salvação.

A Igreja enquanto estrutura na qual o sujeito se acomoda e não implica sua liberdade pode virar uma instância de acomodação das pessoas, assim como, para Juan Luis Segundo, a natureza fechada das coisas pode se tornar motivo de escravidão do homem. De que maneira? "Se o mundo está fixado e determinado pelo divino, a liberdade do homem é um absurdo" (SEGUNDO, 1970, p. 53). São Paulo lutou para que os Coríntios, os Gálatas, os Romanos entendessem que eram os donos do mundo porque o Pai assim o quis. Quis tanto que deu tudo, até o Filho com sua vida. Deus entregou tudo à liberdade humana, ressalvando somente uma coisa: "Vós fostes chamados à liberdade, irmãos. Entretanto, que a liberdade não sirva de pretexto para a carne, mas, pela caridade, colocai-vos a serviço uns dos outros" (Gl 5, 13). Porque é amado infinitamente por Deus, o homem recebeu dele o universo como matéria na qual moldará sua existência livre juntamente com os irmãos. 
Então o cristianismo atual é chamado a aprofundar seu papel de ser fermento na massa, ainda mais porque com o mundo da técnica, que tem realizado profundas transformações, colocando todos em contato com todos, já não facilita mais uma religião que seja expressão única de toda a sociedade. Mergulhados em um mundo pleno, cada pessoa necessita dar conta com mais razão de suas opções, caso não queira tornar-se massa. De alguma maneira, "o cristianismo de massa perde então o que constitui durante séculos sua grande força no Ocidente: a pressão de um ambiente social fechado e unânime. A consequência é evidente, embora muitos cristãos não tenham percebido ainda a amplitude da mudança que isto supõe" (SEGUNDO, 1970, p. 71). Isso significa que numa sociedade cada vez mais plural e técnica, o cristianismo de massa perderá espaço, restando-lhe o que lhe é realmente próprio, ser vivido na autenticidade do amor ao próximo. No contexto da América Latina, a pergunta pelo futuro do cristianismo passa, sobretudo, pelo seu compromisso com a defesa dos projetos das comunidades, das culturas pequenas, para que o ser humano não seja ainda mais manipulado por uma globalização econômica que massacra as minorias sociais. De forma que sua dimensão política torna-se fundamental em tempos de impasses sociais: “separar a religião dos problemas sociais significaria testemunhar e anunciar um Deus indiferente aos clamores dos pobres, insensível ao sofrimento de milhões de seus filhos" (SUNG, 1992, p. 25).

\section{Missão dos cristãos no mundo}

Seguindo o raciocínio sobre a liberdade, em sua expressão inédita que ocorre com o cristianismo, Juan Luis Segundo pergunta-se pela missão cristã nos tempos atuais, em contexto latino- americano, buscando um diálogo com as evoluções científicas, mais especificamente com a teoria da evolução5. Considera que fazer coincidir a conversão de adeptos ao cristianismo simplesmente com a mensagem da vitória de Cristo sobre Adão foi um grande obstáculo na evangelização. É

\footnotetext{
${ }^{5}$ Sobre o diálogo da Teologia com as teorias evolucionistas, conferir principalmenteQue mundo? Que homem? Que Deus? Importante debate entre ciência, filosofia e teologia de Juan Luis Segundo (1995).
} 
fracassada uma pastoral que tente eliminar os condenados de seu meio, como se a comunidade dos eleitos gozasse de um privilégio que os outros não possuem. Em segundo lugar, ocorre o perigo de a pastoral usar meios não convenientes para atrair adeptos. Nesse sentido, o teólogo afirma: "tudo aquilo que aplicado a outros fins pareceria criminoso, foi utilizado pelo sagrado desespero de assegurar, pelo menos no círculo restrito da cultura mediterrânea, esta coextensividade entre sociedade civil e comunidade de adeptos” (SEGUNDO, 1975, p. 9).

Durante longos séculos a coincidência entre vida social e vida cristã gerou uma pertença massificada. Com o iluminismo, abriu-se outro mundo, o do consumo voluntário da religião e, com isso, a pastoral que antes estava submetida à busca cada vez maior de adeptos para o cristianismo, hoje já não pode pensar assim. Inevitavelmente sente-se em crise, procurando resgatar seu sentido mais profundo. E nesse caso, considera-se a relação entre massa e minoria, destacando o seguinte: "o homem a quem o menor esforço leva a preferir e a exigir as soluções mais simples e imediatas dos problemas, este homem é o homem-massa, seja qual for o lugar que ocupa na sociedade, seja ele qualificado ou não" (SEGUNDO, 1975, p. 20). Mesmo o homem de ciência pode, diante de desafios mais complexos, preferir as soluções simples e imediatas, correndo o risco de tomar decisões catastróficas.

É possível fazer uma associação entre a relação de massa e minoria com o princípio da biologia aplicada à evolução da vida, o princípio da entropia, de acordo com a teoria da evolução. Existe naturalmente uma cota de energia constante, distribuída de forma diferente entre os corpos, com tendência geral à degradação, ao desperdício da mesma. Diante do impulso à degradação, a tendência natural é a economia da energia porque dela não se dispõe de uma quantidade infinita. No caso humano, este princípio de entropia, de defesa diante do desperdício energético, num primeiro momento é necessário, mas em seguida gera o homemmassa, aquele que faz opção por trilhar os caminhos já construídos por sua cultura. Já que o desperdício de energia, para que se produza sínteses mais sofisticadas, é 
grande, tende-se a economizar com o preço de permanecer em estado de inércia. De alguma maneira, os humanos tendem a agir como massa, aplicando as soluções mais simples, a lei do menor esforço. O menor esforço é a economia de energia que atinge a todos e até certo ponto é necessário, do contrário a vida seria inviável. Por isso, o mais correto não é a divisão entre massas e minorias, mas condutas de massa e condutas de minoria, que podem ser avaliadas a partir do critério das sínteses mais pobres ou mais ricas. De modo que é difícil pensar numa transformação de uma massa geral sem o compromisso de uma minoria. Toda evolução de uma minoria deve interferir no conjunto, no meio das massas para que elas sejam transformadas. Essa é uma lei da evolução, uma lei ontológica.

Nesse caso, é fundamental pensar como ficam as exigências evangélicas e pastorais diante dessa tensão entre massa e minoria. O Evangelho de Jesus supõe uma decisão em trazer pessoas para o contexto cristão? Será que o Evangelho é uma proposta para conservar as condutas de massas? Ao que tudo indica, o Evangelho parece não ter uma pretensão de adesão explícita de todos, sem esforços, porém possui a intenção de um serviço universal. A aventura da gratuidade de Cristo, que ensina a oferecer a outra face, a amar o inimigo, indica que sua mensagem não é questão de massa, porém de ser fermento na massa. Para exemplificar esse ponto, Juan Luis Segundo analisa a palavra mundo. O que se pode entender por mundo na linguagem de Jesus? Interessa destacar a tensão denunciada pelo Evangelho de João sobre a recusa que o mundo faz em relação ao espírito da verdade (Jo 14, 17). Nesse sentido, mundo é a estrutura que, desde o prólogo de João, não acolhe Jesus, não é objeto sequer de sua súplica. "Não rogo pelo mundo" (Jo 17, 9). João tem uma série de outros textos que falam do mundo, denunciando mundo como estrutura fixa, previsível, máquina. "Eles são do mundo. Por isso falam do mundo e o mundo os escuta" (1Jo 4, 5). Ou seja, "em outras palavras, a ideologia conservadora engana,estabelecendo um círculo fechado onde tudo está fixado: o desejo, o amor, o conhecimento" (SEGUNDO, 1975, p. 36). 
As facilidades favorecem a ideologia porque estão do lado dos caminhos já percorridos, e por isso não implicam, não exigem mudanças. O mundo, em seu sentido fechado, não conhece evolução. Os parentes de Jesus, por exemplo, querem formatar sua novidade a partir dos critérios do mercado comum. "Se fazes tais coisas, manifesta-te ao mundo" (Jo 7,4). Jesus espera sua hora porque sabe que o mundo padece de momentos críticos e nesses tempos de crises há ocasiões favoráveis para se promover saltos. A crise questiona o habitual, o evidente, tudo aquilo que se tornou autossuficiente e mecânico, que talvez no princípio tinha seu caráter de novidade, porém que se perdeu ao longo do caminho, tornando-se costume. A metáfora do nascer de novo mostra a necessidade de romper com a estrutura fechada do mundo (Jo3, 5-7). Então, o pecado fundamental não é ferir a lei, mas negar o sentido político da história, que faz ser operante a liberdade doada ao ser humano para continuar construindo a obra da criação. Nesse ponto, a filosofia da libertação de Enrique Dussel auxilia ao denunciar o sistema neoliberal globalizado como imposição de um modelo excessivamente econômico com pretensões de justificar suas inúmeras vítimas. Mas o mesmo pensamento também alerta que "é por entre as fissuras do poder dominante que a força da comunidade libertadora, aparentemente sempre mais fraca, deve calcular instrumental e estrategicamente suas possibilidades de movimento" (DUSSEL, 2000, p. 562).

A relação do Evangelho com esse conceito de mundo seria de exclusão? Não se pode esquecer também que João afirma que “tanto” amou Deus o mundo. Há, portanto, uma vinculação dos conceitos de mundo e massa como estruturas já dadas, necessárias para a atuação da liberdade. Caso não houvesse as sínteses simples, inertes, não haveria possibilidade de pensar na vitória de sínteses maiores e nem mesmo no sentido mais radical da liberdade humana. Jesus vem salvar o mundo de seu fechamento, lançando-lhe luz. Mas para que a verdade seja luz, deve existir sempre esse núcleo fechado no mundo. "A revelação do amor sem egoísmo algum de Cristo é, ao mesmo tempo, sua glória, a salvação do mundo, o juízo deste e a expulsão daquilo que até agora dominava nele (Jo 13, 1; 15, 22; 12, 31 e 16, 11)” (SEGUNDO, 1975, p. 40). Relacionando o elemento da revelação com a evolução, o 
mundo é vencido e, ao mesmo tempo, permanece como estrutura fechada para o exercício contínuo da liberdade humana. Jesus não salva o mundo desde fora, eliminando dele toda a possibilidade de fechamento, mas num processo de inserção de sua luz. Não se trata de uma passagem quantitativa absoluta do mal para o bem porque a luta continua e as resistências também. "Se eu não tivesse vindo e não lhes tivesse falado, não teriam culpa; mas agora não têm desculpa de seu pecado" (Jo 15, 22). O mundo enquanto estrutura fechada participa do acaso destinado ao exercício da liberdade cristã que, pela força do espírito de Jesus, pode ser transformado continuamente.

Concluindo a exegese sobre o sentido da palavra mundo, seria contraditório ver na luz de Jesus uma possibilidade de adesão massiva, que não respeitasse a aventura das escolhas, das apostas, de uma liberdade humana sempre em processo. É por isso que Jesus faz um chamado ao cristão para que ilumine essa estrutura que permanece desde sempre. Paradoxalmente, sua postura está a serviço da multidão como luz, como fermento. Assim, se o cristianismo se preocupa em ter mais e mais adeptos apenas, seria contraditório porque estaria preocupado em ser uma religião de massa e com isso perderia sua autenticidade evangélica. Além disso, correria no constante perigo de se contentar com os consumidores voluntários de religião, pegando aqueles que não têm possibilidade de rejeitá-lo. Ainda mais, a atitude minoritária evangélica está a serviço da multidão porque compreende que é necessário o ordinário para que surja o extraordinário; é preciso crise para que apareça a liberdade operosa. "Em outras palavras, a pastoral reconhece algo que até agora praticamente nunca era reconhecido: o valor teológico do momento da mensagem evangélica, o fato significativo de que não tenha sucedido nem antes, nem depois, mas em sua hora" (SEGUNDO, 1975, 44).

No quesito do amor ágape, portanto, supõe-se, a partir da teoria da evolução, que ele não seria possível em outra época. Porém chegou o tempo da maturidade energética possível na qual o ser humano começou a ser capaz de viabilizar tal amor. Pastoralmente, é sempre necessário colher a energia viável do 
cristianismo ou não. Enfim, há muitos elementos que devem ser resolvidos pela massa e por isso o cristianismo não tem todas as respostas. O mundo permanece morada do ser humano e permanece como estrutura fechada até que chegue a hora da graça, das sínteses mais ricas de amor e para essa hora existe o testemunho do cristianismo que autoriza o ser humano a confiar na liberdade recebida do criador para criar novas saídas, dar novos passos desde que não seja para reforçar o egoísmo mundano. Depois dessa descrição sobre o significado de mundo como estrutura fechada e do cristianismo enquanto fermento, o que poderia ser dito da plausibilidade do cristianismo num contexto latino-americano profundamente colonizado pelos valores imperialistas do mercado que possui uma estrutura midiática a seu livre serviço?

\section{A Igreja como fermento na massa}

A questão das massas é problemática para a teologia, sobretudo quando ela tem a tarefa de responder sobre o universalismo da fé cristã. Mesmo que o cristianismo seja o caminho que pregue a universalidade salvífica em Cristo, isso não significa ainda que ele deve ser uma religião de massas. Apesar de o cristão saber que sua missão é transformar as massas pela conversão do coração e pelas transformações históricas, sabe também que nenhuma conquista social traduzirá em absoluto o Reino de Deus. Por isso, a fé cristã é sempre portadora de uma latente crise, que em meio a todo engajamento não perde o senso crítico porque seu princípio é de que a liberdade é um processo contínuo de resposta ao amor de Deus. A liberdade, na perspectiva paulina, apresentada por Juan Luis Segundo, é condição de possibilidade para o ser humano agir de maneira transformadora no mundo, guardando sempre uma reserva de sentido para que a construção continue.

Se Deus comunica algo que transforma, que acrescenta, que faz o ser humano mais, autorizando sua liberdade a percorrer o caminho da transformação, tal percurso não acontece de maneira mágica, vinda de fora e que opera sem o consentimento do ser humano. O Concílio Vaticano II é incisivo em afirmar, de 
modo particular em GaudiumetSpes, que Cristo transfigura o sentido mais radical do ser humano, convocando-o a uma "fraternidade universal" (GS 3). Por isso, longe da revelação afastar o homem da terra, dirigindo-o para uma realidade abstrata, eterna, "orienta a mente para soluções plenamente humanas" (GS 11). De modo que mesmo de posse da verdade revelada, diante de conflitos, situações concretas, o cristão deve estar em diálogo contínuo para a construção da verdade da qual ele não tem posse absoluta. Como estrutura-se antropologicamente a fé na revelação de Deus na história e quais suas consequências pastorais?

Para Juan Luis Segundo, a história é uma aposta da qual não se sabe o final. Em toda escolha existe um ato de fé. É claro que não se vive às cegas. A própria sociedade oferece ao sujeito modelos, testemunhos que apóiam seus projetos, que servem de parâmetros para confiar nas escolhas. Chama-se essa fé de antropológica e a prova mais interessante de que ela existe acontece no fato de as pessoas pagarem preços custosos por coisas das quais não se tem certeza de que sejam satisfatórias. Por isso, mesmo que ainda não se trate de um Ser absoluto, cada pessoa constrói seu horizonte antropológico com valores que ela considera absoluto. Valores inegociáveis, sem os quais ela mesma não se compreende. São escolhas baseadas no próprio sentido que cada ser humano elege para apostar sua vida e correr o risco rumo a construção de um sentido existencial. Falar de libertação cristã do ser humano sem considerar tais horizontes antropológicos não seria possível.

Portanto a libertação da liberdade trazida pelo evento Jesus Cristo, não chega ao homem como dado extrínseco e totalmente estranho à sua realidade antropológica. Ela somente é escutada e acolhida porque já existe uma estrutura significativa, um existencial de busca que leva o homem a acolhê-la como algo que acrescenta em sua existência. É preciso salvaguardar também que Deus não bate à porta do ser humano senão por uma livre graça e o faz não para confirmar somente o que o ser humano já tem (Ap 3, 20). Ele revela-se para fazer o ser humano ser mais do que é. Deus interpela o ser humano a partir de seu existencial significativo 
para que ele torne-se sempre mais humano. Diante desse aspecto, o Concílio Vaticano II chama atenção para o problema do ateísmo e de suas variações na cultura atual. Muitos não notam que a radical felicidade do homem é o amor de Deus. Alguns chegam a afirmar que para o ser humano ser de fato livre, deve livrarse do divino, que cientificamente não goza de prova alguma. Outros repudiam as imagens feitas de Deus ou até entram em total indiferença em relação às problemáticas religiosas. Porém, há que considerar que para muitos ateus são os próprios crentes em sua má vivência da fé que dão argumentos suficientes para ser ateu (GS 19).

É na estrutura significativa como fé antropológica que Deus se revela. E o faz para indicar o caminho da responsabilidade da liberdade humana criativa. É preciso focar no processo pedagógico que significa muito mais do que ensinar coisas prontas. A relação entre Deus e homem supõe processos, buscas e amadurecimento do próprio homem. Para responder à pergunta sobre a injustiça que acontece com o justo, o homem de fé alcançará, um dia, o fato de que a justiça sobrevive à morte $(\mathrm{Sb} 1,15)$. Certamente se Deus desse informações ao ser humano que ainda não tivesse maturidade para acolhê-las, seguramente tais informações, por não respeitarem processos históricos, não entrariam no coração do homem e não ganhariam a posteridade. Diante disso, constata-se que a revelação divina não é uma simples proposta de uma verdade fixa, inalterável, sem a implicação das decisões humanas. A revelação cristã acontece como luz no seio das buscas históricas do homem. Muito mais do que revelar verdades absolutas sobre si mesmo, o Deus cristão mostra-se como amor que se faz carne, que se faz história, para que o desenrolar das lutas humanas sejam iluminadas desde dentro por uma presença interpeladora para a construção do bem6.

\footnotetext{
${ }^{6}$ Ver As etapas pré-cristãs da descoberta de Deus, (SANCHIS; SEGUNDO, 1968), como fonte primordial para aprofundar a relação da revelação divina com a história e avaliar tais etapas presentes ainda hoje na realidade cristã latino-americana.
} 
E precisamente nesse sentido encontra-se a missão da Igreja como testemunho do processo salvífico de Deus na história. Para sua atualização pastoral, a comunidade de fé necessita perguntar-se: o excesso de informações, muitas vezes precipitadas, sem a laboriosa pedagogia de um cotidiano que respeita o processo de amadurecimento das pessoas não seria um dos graves problemas da pastoral atual? Instruções fora do tempo e de formas impositivas dariam conta de sustentar um processo autêntico de evangelização? A revelação mostra muito mais o como Deus age do que um conjunto de leis fixas para serem obedecidas. Deus age com amor e isso deve ser transmitido como estilo de vida cristã que deve ser aprendido na comunidade. Se a revelação acontece numa história humana aberta para acolher a Palavra de Deus que o fará ainda mais humano, e se a Bíblia, conforme afirma Dei Verbum, possuilinguagens transitórias e imperfeitas, a revelação precisa de um testemunho da comunidade para que seja anunciada. Ela deve tornar-se tradição. A tradição não é uma fonte separada, porém uma sabedoria que se transmite numa comunidade viva, a Igreja. O testemunho da tradição faz com que cada nova geração não tenha que começar do zero, podendo avançar rumo à verdade sempre mais cabal, e isso é sumamente importante para a revelação. De modo que a fé não se trata de pura adesão a uma verdade já acabada à qual o homem necessita passivamente acolher. Ela caracteriza-se por movimentos da bondade de Deus na história. Movimento dos quais a humanidade é chamada a participar ativamente no exercício da construção de um mundo que ainda está por ser feito. Esse movimento esclarece porque a tradição não é somente algo fixo, escrito em um livro, mas o testemunho vivo de uma comunidade que é mistagoga.

Se a Igreja é uma instância crítica e mistagógica, que não aceita a organização massiva do cristianismo, precisa ela tomar partido político? A principal missão dos cristãos é a de sustentar o senso crítico em relação a qualquer postura política. Guardar-se como instância crítica dos ídolos, da forma fechada do mundo, não significa que a Igreja seja indiferente aos processos de transformação da realidade. Muito ao contrário, ela estará sempre comprometida com a conversão 
de toda forma fechada, alienada, trazendo-lhe a firme convicção que jamais se descansará de sua missão em favor do Evangelho. Neste ponto encontra-se a especificidade do ser cristão no mundo. Toda pessoa tende a se acomodar em sua forma de massa e mesmo as grandes reflexões ou conquistas nem sempre estão a favor das sínteses mais ricas de energia. "A verdade da mensagem cristã não é, pois, uma verdade teórica da qual se possa dispor antes da praxe. É um fazer a verdade, segundo a expressão de João, pelo qual se ilumina o próprio horizonte teórico para enriquecer ainda mais a praxe libertadora” (SEGUNDO, 1975, p. 74).

No entanto, se todos os homens escolhem um caminho e se implicam com ele sem terem a segurança prévia de seu destino, de sua felicidade, o que significa sempre uma fé antropológica, como entender a passagem de uma fé antropológica para a dimensão mais radical da fé no absoluto? Juan Luis Segundo afirma que é necessário fazer a passagem do cordão umbilical que liga toda fé humana às situações categoriais, como a figura dos pais, de algum líder, para algo mais radical. Essas situações precisam ser relativizadas para que se descubram realidades mais profundas que tais relações ocultam. De outro modo, afirma que:

a desinstalação fundamental que me faz transcender os testemunhos cristãos relativos que me rodeiam, a que me projeta em forma auditiva e aberta para o próprio Jesus, a que fundamenta minha fé nele e em nenhuma outra pessoa, por mais confiança e atrativo que me inspire, aparece no horizonte de compromisso político e de compromisso político revolucionário em favor dos oprimidos (SEGUNDO, 1975, p. 91).

A chave política, para Segundo, é a que melhor abre a vida de Jesus como fonte genuína de transformação da história e como ação pastoral dos cristãos. Política como busca do poder, certamente não é a de Jesus, porém tudo que o ser humano faz e que ajuda a construir a comunidade humana trata-se de verdadeira política. Jesus foi profundamente político. Restringir, portanto, o cristianismo como religião, como se houvesse uma chave exclusivamente religiosa na vida de Jesus, causa confusões em sua compreensão. A revelação de Deus, realizada pela globalidade da vida de Jesus, passa pela mediação humana, pela história, pela vida 
política. Deus não se revelou de fora de tudo isso. É precisamente nas estruturas humanas que se constrói o Reino de Deus na terra, iluminando até mesmo as ideologias opressoras presentes também em formulações religiosas. E a Igreja é a comunidade chamada a testemunhar o amor que precisa ser concretizado e que, como ágape, no entanto, ultrapassa toda construção categorial.

\section{Conclusão}

Conclui-se que a questão da liberdade merece ainda ser aprofundada pela Teologia, sobretudo no que tange as necessidades de repensar a práxis cristã latinoamericana, na pós-modernidade. Conceber o homem como herdeiro de um universo e não como criatura que se encontra apenas diante de um campo de prova, é um dos grandes horizontes para um verdadeiro diálogo entre a fé e os tempos atuais. De tal maneira que a liberdade, nesta perspectiva, consiste em acolher o dom de Deus e com ele criar, num processo contínuo de parceria entre criatura e criador. Deus cria do nada, o homem cria a partir dos elementos que Deus lhe concedeu no acaso do universo, obra incompleta, que espera pela ação humana. Isso implica acreditar que, de alguma maneira, Deus cessa de intervir na criação para não cercear a liberdade humana. Mais ainda, a kênosis do Filho revela ao ser humano que a dignidade da liberdade encontra-se precisamente na práxis fraterna que é a defesa sobretudo das vítimas que todo sistema produz.

A partir das descobertas evolucionistas, é possível apostar que viver profundamente a liberdade significa entrar em processos que elevam as condições narcísicas do amor ao seu nível ágape. De modo que o ser humano somente cria ao modo de Deus, quando compromete-se com o amor que é capaz de incluir até mesmo o inimigo ou aquele que não pode dar nada em troca. Gratuidade que inverte a lógica da reciprocidade e suas justificativas vitimárias, instaurando o tempo de uma liberdade capaz de lutar pela promoção dos que vivem em situações de exclusão. Ou seja, o egoísmo não é um destino, mas o resultado imediato da 
liberdade que opta pelas facilidades de uma estrutura mundana já pronta. A maturidade filial desinibe o medo da liberdade e a eternidade será a plenitude dos gestos amorosos históricos. A singularidade cristã consiste precisamente que na história encarnada de Jesus Cristo a liberdade humana é libertada de sua possível acomodação aos cenários fechados das construções amorosas, sobretudo das amarras da injustiça. A Páscoa cristã autoriza, assim, na força geradora do espírito, ao homem percorrer de maneira sempre nova os caminhos que elevam o amor egoísta à inusitada experiência de ágape.

Nos cenários latino-americanos, ocorre que muitas pessoas ficam inseguras diante de uma generalizada busca pelo bem individual em detrimento das construções sociais. Contexto que é reforçado pela mídia atrelada a um mercado que supervaloriza a dimensão econômica do ser humano. A vida ganha uma áurea de espetáculo que nem sempre sustenta as demandas existenciais, gerando um clima de fragmentação que, ao extremo, pode conduzir ao caos pessoal e grupal. Se, por um lado, as descobertas hermenêuticas apostam no grande valor da democracia, do diálogo e da interpretação diversa como vias importantes de um tempo sem a rigidez das grandes instituições possuidoras da verdade; por outro lado, a sociedade necessita construir pontes que favoreçam indivíduos e grupos no fortalecimento de uma liberdade empenhada pela gestação de caminhos que não sejam simplesmente o domínio de eros em detrimento de ágape. Tal convicção confirma que a missão da Igreja, de ser fermento na massa, será profundamente importante quanto mais a comunidade de fé estiver empenhada no incentivo das pessoas em comprometerem sua liberdade na construção de sínteses amorosas mais ricas. Por isso, é necessário o testemunho profético da comunidade que implique a liberdade humana no combate contínuo de estruturas que enfraquecem a dignidade humana, sobretudo dos mais pobres.

Por fim, propõe-se que a dimensão mística e poiética seja fundamental para aprofundar o sentido de ser religioso na contemporaneidade. A sensibilidade das 
pessoas é muito aguçada no que tange a estética. A Igreja, sempre defensora da arte como morada do divino, deve continuar propondo ao homem pós-moderno a tornar-se sempre mais imaginativo na gestão de sua existência. A Igreja com sua larga tradição de beleza seja na música, na poesia, pode e deve incentivar esse sujeito a recriar suas relações, compondo sobretudo comunidades afetivas e efetivas na vivência do amor ao próximo, realidade que traz consigo não somente a dimensão do compromisso, mas da festa enquanto antecipação da alegria do Reino de Deus. Portanto, no combate das estruturas injustas, a dimensão da celebração é lugar privilegiado para o fortalecimento da beleza de ser cristão em contextos nos quais a morte, muitas vezes, pesa sobre os ombros de grande parte das pessoas.

\section{REFERÊNCIAS}

BAPTISTA, Paulo Agostinho N.; SANCHEZ, Wagner. L. (Orgs.) Teologia e sociedade. Relações, dimensões e valores éticos. São Paulo: Paulinas, 2011.

BÍBLIA de Jerusalém. São Paulo: Paulinas, 1986.

COMBLIN, José. Vocação para a liberdade. São Paulo: Paulus, 1998.

DOCUMENTOS do Concílio Vaticano II. Rio de Janeiro: Vozes, 1966.

DUSSEL, Enrique. Ética da libertação. Na idade da globalização e da exclusão. Petrópolis: Vozes, 2000.

GUTIÉRREZ, Gustavo; MÜLLER, Gerhard L. Dalla parte dei poveri. Teologia della liberazione, teologia della chiesa. Padova: Mensaggero di Sant' Antonio, 2013.

MENDOZA-ALVARES, Carlos. O Deus escondido da pós-modernidade. Desejo, memória e imaginação escatológica. Ensaio de teológia fundamental pós-moderna. São Paulo: Realizações, 2011.

MENDOZA-ÁlVARES, Carlos (Comp.) Qué es hoy la dignidad humana? Ciudad de Mexico: Universidad Iberoamericana, 2015.

PIERRE SANCHIS, Joseph; SEGUNDO, Juan Luis. As etapas pré-cristãs da descoberta de Deus. Uma chave para a análise do cristianismo (latino americano). Petrópolis: Vozes, 1968. 
RUBIO, Alfonso Garcia; AMADO, Joel Portella. Fé cristã e pensamento evolucionista. São Paulo: Paulinas, 2012.

SEGUNDO, Juan Luis. A concepção cristã do homem. Petrópolis: Vozes, 1970.

SEGUNDO, Juan Luis. Massas e minorias na dialética divina da libertação. São Paulo: Loyola, 1975.

SEGUNDO, Juan Luis. Salvos ...de que? In: SEGUNDO, Juan Luis. Da sociedade à Teologia. São Paulo: Loyola, 1983. p. 75-106.

SEGUNDO, Juan Luis. Que mundo? Que homem? Que Deus? Aproximações entre ciência, filosofia e teologia. São Paulo: Paulinas, 1995.

SUNG, Jung Mo. Deus numa economia sem coração. Pobreza e neoliberalismo: um desafio à evangelização. São Paulo: Paulus, 1992. 